\title{
RN Revista de Negócios
}

\section{Financial \\ incentives in \\ experiments: a theoretical and empirical debate}

\author{
Marco Goulart ${ }^{1}$, Newton Carneiro Affonso da Costa Jr. ${ }^{2}$, Jéssica Pulino \\ Campara $^{3}$, Ana Luiza Paraboni ${ }^{4}$ \\ ${ }^{1}$ Federal University of Santa Catarina - marcoaovg@gmail.com \\ 2 Pontifical Catholic University - ncacjr@gmail.com \\ 3 Federal University of Santa Catarina - jecampara@gmail.com \\ ${ }^{4}$ Federal University of Santa Catarina - anaparaboni@gmail.com
}

KEYWORDS

Behavioral economics, Behavioral finance, Financial incentives, Disposition effect.

Received 11.03.2019 Reviewed 18.09.2019 Accepted 28.10.2019

ISSN 1980-4431 Double blind review



ABSTRACT

The use of financial incentives in experimental economics gained recognition from Smith's seminal work (1962; 1976). However, although this practice is widely adopted internationally, it is still little used in Brazil. Noticing such gap, the objective of this article is to evaluate the impact of the use of financial incentives in experiments in the area of economics and finance. To this end, a simulation of computational investment using ExpEcon was performed with 106 undergraduate students from UFSC. The objective was for them to perform stock purchase and sale operations and with this data it was possible to estimate the variables of the research: disposition coefficient, proportions of realized gains and realized losses. For the analysis, t-tests and multiple regression were estimated in order to assess the impact of financial incentives on the results. To support the discussion, in addition to the theoretical framework, National Health Council (CNS) resolutions No. 466 and No. 510 were discussed. The main results show that there is a need for clearer regulations regarding financial incentives. The results also brought empirical confirmation that financial incentives can alter the behavior of individuals as in the case of the disposition effect. Thus, the originality and importance of this study is highlighted, given that it contributes to the literature not only at the theoretical level, but also by presenting an empirical essay corroborating the theoretical discussion. Such findings and debates do not cease the discussion but foster and encourage critical thinking about financial incentives in experiments in the area.

\section{PALAVRAS-CHAVE}

Economia comportamental, Finanças comportamental, Incentivos financeiros, Efeito disposição.

\section{RESUMO}

O uso de incentivos financeiros em economia experimental passou a ganhar notoriedade a partir dos trabalhos seminais de Smith $(1962 ; 1976)$. Porém, apesar desta prática ser amplamente adotada internacionalmente, no Brasil ainda é pouco utilizada. Percebendo tal lacuna, o objetivo deste artigo é avaliar o impacto do uso de incentivos financeiros em experimentos na área de economia e finanças. Para isso, foi realizada uma simulação de investimento computacional utilizando o ExpEcon com 106 alunos de graduação da UFSC. O objetivo era que eles realizassem operações de compra e de venda de ações e com esses dados fossem calculadas as variáveis da pesquisa: Coeficiente de Disposição, Proporções de Ganhos Realizados e Perdas Realizadas. Para a análise foram estimados testes $t$ e regressão múltipla, com o objetivo de avaliar o impacto dos incentivos financeiros nos resultados da pesquisa. Para dar embasamento a discussão, além do referencial teórico foram discutidas as resoluções №466 e №510 do Conselho Nacional de Saúde (CNS)Os principais resultados mostram que existe a necessidade de resoluções mais claras a respeito de incentivos financeiros e trouxeram a confirmação empírica de que incentivos financeiros podem alterar o comportamento dos indivíduos como no caso do efeito disposição. Destaca-se, então, a originalidade e a importância deste estudo, dado que contribui com a literatura não apenas no âmbito teórico, mas também ao apresentar um ensaio empírico corroborando a discussão teórica. Tais achados e debates não cessam a discussão, mas fomentam e incentivam um pensamento crítico a respeito de incentivos financeiros em experimento na área.

Revista de Negócios, v. 4, n. 24, p. 7-21, October, 2019. 


\section{Introduction}

During the 1960s, social psychologist Stanley Milgram conducted an experiment on obedience (Milgram, 1963).

Even today, this research, also known as Milgram's obedience experiment, is widely cited in the field of social psychology and other areas of scientific knowledge. What little is said today is that Milgram received strong opposition from his fellow researchers, who considered his experimental methods unconventional and even unethical.

Many years later, it became evident that Milgram's discoveries far outweighed the possible, unproven damage to the participants in the social experiment. In spite of the broad ethical discussion that took place at the time, even today a conflict still prevails about ethics in social experiments. One example of this is the use of economic experiments, more specifically with regard to offering financial incentives to participants.

The use of economic experiments and the discussion on the use of financial incentives gained ground mainly after the seminal works of Vernon Smith (1962; 1976), who in 2002, together with Daniel Kahneman, received the Nobel Memorial Prize in Economic Sciences. Since then, the use of financial incentives in economic experiments is a practice adopted in several research centers around the world (Bricker, 2014; Carpena et al. 2015; Harrison, 1989; Camerer \& Hogarth, 1999; Holm et al., 2013; Cárdenas et al. 2014; Feltovich, 2011).

Despite the international importance that the experimental economy receives, in Brazil it is not possible to notice the same degree of success. According to the directory of research groups of $\mathrm{CNPq}$, it is observed the existence of only two research groups that bring the theme "experimental economy" in its name. The Laboratory in Experimental Economics and Complex Systems was created in 2016 at the Universidade Estadual Paulista Júlio de Mesquita Filho (UNESP) and more recently the Laboratory of Applied Studies in Behavioral and Experimental Economics at Universidade Tiradentes (UNIT), created in 2019, that is, during the period of this research it had not yet been constituted. Even with the existence of other research groups and some laboratories in a few universities such as the Pontifical Catholic University of Rio de Janeiro (in general, not in public federal universities), the incipiency of the theme in the national territory is noteworthy.

In addition, in a survey conducted in 118 journals under CAPES' Qualis system in the areas of Administration, Accounting, Tourism and Economics, the main vehicle for dissemination of these works, we identified 147 papers that adopted the experiment as data collection until April 2017. Of these, only 8 provided some kind of incentive to their participants, and only two did so with financial resources (Póvoa, Maffezzolli, Pech \& Silva, 2017; Antiqueira, Saes \& Lazzarini, 2007; Iwai \& Azevedo, 2016; De Lima, Porto \& Botelho 2016; Costa et. al, 2014; Dos Santos, 2015; Passos, Cornacchione Jr; Gaioa; Brito, 2016; Dantas, Dantas, \& Silva, 2012).

We can conjecture that one of the obstacles to the expansion of experimental research with financial incentives in Brazil is the interpretation that is made of the National Health Council (CNS) resolutions No. 466 of December 12, 2012, and No. 510 of April 7, 2016. These regulations address the guidelines and regulatory standards for research involving human beings. They are, therefore, the regulations adopted by the Ethics Committees that previously analyze and approve the conduct of any research, including those in the field of experimental economics.

Seeking to better understand this context, the main objective of this work is to evaluate the impact of the use of financial incentives in experiments in the area of economics and finance. Specific objectives include: i) developing a theoretical review on experimental economics and the use of financial incentives that can guide the empirical discussion; ii) conducting a review of Resolutions of the National Health Council (CNS) No. 466 of December 12, 2012, and No. 510 of April 7, 2016; and iii) presenting an empirical essay on the influence of financial incentives on the disposition effect.

Within this context, we will have the opportunity to explore the use of financial incentives in economic experiments both in the legal requirements, through the analysis of regulations, as well as theoretical and empirical. With this, we have first contributed to the discussion on the development of experimental researches, as well as the use of incentives in such researches, since at national level this is a topic

Revista de Negócios, v. 4, n. 24, p. 7-21, October, 2019. 
little explored in comparison with more developed countries. The legal basis for this discussion provides a possible practical impact for future research. We hope that the debate here outlined will allow less doubt regarding the interpretation of the aforementioned resolutions and this will facilitate the adoption of this practice in Brazilian experiments.

Finally, it is important to consider this discussion not only at the theoretical level, but also by presenting an empirical essay that corroborates the discussion that financial incentives can have an important impact on the results of experimental research. With the present study we hope to minimize the existing gap in Brazil of the need for researches with national samples that evaluate the impact of financial incentives in experiments, since until the present moment that we finalized this article only one Brazilian study was dedicated to perform this comparison, and the variable evaluated was the risk aversion (Soares, Simões \& Jorge Neto, 2018).

This paper begins with this introduction, starting with a presentation of a theoretical review on experimental economics and financial incentives. Subsequently, a discussion of the referred resolutions, debating the points related to the use of financial incentives. The third part presents an essay analyzing the influence of financial incentives on a widely debated anomaly in behavioral finance: the disposition effect. Finally, conclusions and recommendations are presented in order to discuss the use of this important scientific method.

\section{Theoretical Framework}

Since its dissemination in the 1960s, much has been debated at the international level about the use of financial incentives in experiments. It can be said that most of the work points to the need for the use of financial incentives, in order to engage the participant of the experiment. However, some studies show that the use of financial incentives is dispensable, or that it can be replaced by the use of other means of incentives, such as extra points in notes for the case of student participants. The objective of this session is to present the main research that deals with the use of financial incentives in economic experiments.

\subsection{Financial Experiments and Incentives}

Given the complexity in capturing the real behavior of individuals in the decision-making process, experimental research emerges as an alternative in this direction, since in this type of study the researcher ends up having greater control of the variables surveyed compared to the field, thus having the possibility of changing certain parameters (Feltovich, 2011). One of these parameters would be to allocate some financial reward to research participants.

However, there is no consensus in the social sciences regarding the validity of financial incentives, especially in relation to studies in psychology and economics. Thus, although the combination of these areas of knowledge has the potential to offer a deeper understanding of social issues, there seems to be a gap between the studies of the two areas, so that psychology researchers believe that the costs and benefits of different courses of action in the real world are often undefined, causing the rewards of the laboratory to decrease the realism of research (Ariely \& Norton, 2007). Moreover, for researchers in this field of studies, subjects do not need rewards due to the fact that the intrinsic motivation is already high enough for them to undertake efforts (Camerer \& Hogarth, 1999).

On the other hand, when investigating studies in the area of economics, it is possible to observe a greater consensus that the financial incentives offered to the participants of the experiments positively affect their performance, as well as increase the credibility of the data (Holm et al., 2013), so that if they were not paid, there would be no cognitive effort in order to avoid errors of judgment (Harrison, 1989; Camerer \& Hogarth, 1999).

Hertwig and Ortmann (2001, p. 390) assume four main reasons why research in this area should use financial rewards. First, the authors claim that when monetary incentives are offered, the variability of performance decreases among participants. Then, one has the idea that this type of incentive is easier to evaluate and implement than the other types, as well as most individuals are enthusiastic about the possibility of earning more, not having satiety throughout the experiment. Finally, the authors argue that most of

Revista de Negócios, v. 4, n. 24, p. 7-21, October, 2019. 
these studies test an economic theory, which predicts assumptions of maximizations, as well as defines behavior patterns that can be more reliable with reward.

On the other hand, there is also research in the economic field that questions some aspects of financial incentives. Cárdenas et al. (2014), raise the question that the monetary incentive offered, for being easily achievable, may not portray a real life situation, which is known as house-money effect. In this sense, the authors suggest a deepening in the studies regarding the time elapsed between the transfer of a reward and the experimental decision, because according to them, if the incentive is provided days before the study, individuals can have this value as part of their real incomes.

Bricker (2014) compares the quality of data and attempts to contact families who were invited to participate in the Survey of Consumer Finances (SCF), a survey conducted every three years in the United States. Some families were offered monetary incentives and others were not. In the first instance, the author found a faster acceptance of the benefited families to participate in the study compared to other families, as well as when comparing the value offered in 2007 (\$20) and 2010 (\$50). Bricker (2014) realized that the higher the value offered, the faster the adhesion is. However, in view of the results, it was possible to observe that the quality of the data and the effort required in the research were little affected by the reward offered. Given this, the author linked these results to the fact that most of the sample contains individuals with above-average income, so that the reward offered is not seen as something attractive, contrary to what happens with people with lower purchasing power.

In order to explore which aspects of financial education interventions facilitate economic decision-making, Carpena et al. (2015) investigated 1,500 individuals in India and offered rewards to each individual according to the number of correct questions they were asked, given that the questions were related to a video presented to participants. Thus, the authors sought to verify whether the monetary incentives could induce participants to retain and apply the knowledge taught during the experiment, but at the end of the research, they realized that the inclusion of payments related to the performance of each individual did not result in any significant improvement in the financial knowledge acquired by them, either in the short or long term.

Similarly, in reviewing 74 experimental studies, Camerer and Hogarth (1999) observed that financial incentives do not always improve each individual's performance. The authors concluded that high rewards have greater effects only on the tasks of judgment and decisionmaking, considered the easiest tasks, and that monetary incentives are harmful when the problems are more complex or, even, when a simple intuition provides an optimal response and thinking more deeply ends up worsening the situation of the subject.

\subsection{Disposition Effect}

The disposition effect was originally studied by Shefrin and Statman (1985), who explain it through four important elements: prospect theory, mental accounting, regret aversion and selfcontrol. Odean (1998) later included reversion to the mean explanation.

The first component, prospect theory, is proposed by Kahneman and Tversky (1979), who state that individuals are risk-averse for gains, but risk-seeking for losses. In relation to mental accounting, the central point is that decision makers tend to segregate the different types of choices into separate accounts, ignoring any kind of interaction between them. Regret aversion, on the other hand, refers to the fact that investors tend to be reluctant to make losses, since at this time they are forced to admit their own mistakes. Self-control refers to an existing conflict between the rational and the emotional side of the individual. Finally, the reversion to the mean corresponds to the belief that assets that are significantly depreciated could increase in value and assets that are appreciated could be devalued, converging to the mean.

In recent years other studies have investigated the factors that influence the susceptibility of individuals to the disposition effect. Among the findings, there are issues such as socio-demographic characteristics (Feng \& Seasholes, 2005; Dhar \& Zhu, 2006), investment experience (Chen, et al., 2007; Calvet et al., 2009; Da Costa Jr. et al., 2013), psychological conditions related to the establishment of savings targets (Aspara \& Hoffmann, 2015), emotions such as regret, which make investors maintain 
capital losses, and joy that make them realize capital gains (Summers \& Duxbury, 2012), and psychophysiological characteristics - individuals with higher sweating, heart rate and body temperature tend to have greater disposition effect (Goulart at al., 2013).

From the determinants of the disposition effect, we now seek to understand how it is measured. From the moment the method used to calculate the disposition effect started to be seen as important for its outcome, several attempts were made to reach an efficient measurement. Thus, after the estimate suggested by Shefrin and Statman (1985), emerged the one proposed by Odean (1998), which can be considered one of the most used, and uses the frequency with which investors sell winning and losing shares in relation to the opportunity to sell both in a situation of profit and loss. Subsequently, other measures that represent an evolution in the studies of this behavioral bias emerged (Dhar \& Zhu, 2006; Barberis \& Xiong, 2012; Kaustia, 2010).

The studies on the disposition effect can also be divided according to the data collection method used, so that they can be based on actual market data (Odean, 1998), based on controlled experiments (Weber \& Camerer, 1998), and controlled experiments using the computer system (Goulart et al., 2015).

\section{Resolutions of the National Health Council (CNS) and its Interpretations}

We began the debate by Resolution 466 (R466) of the CNS of 2012, which deals with the guidelines and regulatory standards for research involving human beings. For this reason, its use is the basis for the decisions of Ethics Committees throughout the country. Thus, a detailed reading of R466 allows the reader to observe that its wording takes into account several aspects of research in the area of health and biological sciences, without leaving clear guidelines regarding research in the context of the Human and Social Sciences. Realizing this gap, in 2016 a new resolution was published (R510), in which the CNS sought to recognize the ethical peculiarities of research in the Human and Social Sciences, however the theme on financial incentives is not directly addressed.

Specifically, in relation to $\mathrm{R} 466$, it is perceived a focus on the peculiarities of research in the health field. In this sense, several concerns are raised, such as research involving human reproduction and/or biological materials (item "II terms and definitions"), studies with pregnant and lactating women (item "III Of the ethical aspects of research involving human beings"), procedures with subjects with brain death or indigenous population ("IV of the free and informed consent process"), among many others. However, although R466 is coherent and complete regarding the aspects of research in the health area, some of its paragraphs raise doubts of interpretation when it comes to its application in research in the area of experimental economics. Item II, number 10 indicates that the research participant is:

"The person who, in an enlightened and voluntary manner, or under the clarification and authorization of his or her legal guardian(s), agrees to be researched. Participation must be free of charge, except for Phase I or bioequivalence clinical trials;". $\left(R . N^{o}\right.$ 466 of 12/12/2012)

This elucidation leads many ethics committees to limit the use of monetary incentives.

On the other hand, it is common for research in experimental economics to offer a financial value for subjects to perform a given activity, and in many cases this value may increase or decrease depending on the performance of participants. An example is participation in an investment simulation where those who exceed the market index receive an extra value and those who fail to exceed lose a portion of the value they received (Da Costa Jr. et al., 2013).

In this sense, by requiring participation free of charge, the resolution raises a question of interpretation about the possibility of a participant receiving a monetary value and putting this value at risk during the experiment. If the value is previously offered, and the subject has a poor performance, then he would have to "pay" a value that is already in his possession. It would be possible to argue otherwise, claiming that the research participants do not hold the monetary resource before the end of the experiment.

Also, in item II, paragraph 18 defines what is "prior provision of material", and a similar wording is used in paragraph 21 to define

Revista de Negócios, v. 4, n. 24, p. 7-21, October, 2019. 
"reimbursement":

"cash compensation, exclusively for transportation and food expenses of the participant and his/her companions, when necessary, prior to his/her participation in the research;". (R. $N^{o} 466$ of 12/12/2012, II, §18)

This paragraph may generate a limitation for the researcher in experimental economics who intends to perform the payment of participants only after the research, as previously highlighted. The text also requires that payment be only for transport and food expenses, which excludes the use of monetary compensation so that the participant is effectively engaged in the procedure - the issue of engagement will be dealt with in more detail in the next item.

Item III, paragraph 2, line "i" states that research in any area of knowledge involving human beings shall:

"provide for procedures that ensure confidentiality and privacy, protection of the image and non-stigmatization of research participants, ensuring that information is not used to the detriment of individuals and/or communities, including in terms of self-esteem, prestige and/or economic and financial aspects; $;^{\prime \prime}$ (R. $N^{o} 466$ of 12/12/2012)

This passage imposes a condition of confidentiality that may not be of interest to a particular experimental design in economics. In Goulart et al. (2015), for example, the experimental design predicted a potentially embarrassing situation. Because the research participants should reveal their financial performance, in a simulation of investments, publicly. The use of this type of experimental design is important since many financial decisions are not made individually, but in front of a group, just as there are real situations where the results are shared and the performance is made public (Endlich, 2000; Derman, 2004).

As a counterpoint to the passages that apparently oppose the procedures used in experimental economics, R466 also highlights the validity of research that brings benefits to the scientific debate.

"direct or indirect income, immediate or posterior, earned by the participant and/or his community as a result of his participation in the research". ( $R . N^{o} 466$ of 12/12/2012, II, §4)

On the other hand, R510, which follows an editorial style similar to R466 in many of its paragraphs, sought, in some way, to offer an opening to the ethical peculiarities of research in the Human and Social Sciences. The main highlight of R510 is the text on the "free participation" of the researched subjects. The text that defines the "research participant" was as follows in R510:

"individual or group, who is not a member of the research team, participates in it in an informed and voluntary manner, by granting consent and also, when appropriate, by assent, in the forms described in this resolution. $\left(R . \quad N^{o} 510\right.$ of 04/07/2016, art. 2, § XIII)

It is noted the exclusion of the requirement of free participation that had been proposed by R466. However, in its final provisions (chapter VII) R510 suggests that "in situations not covered by this resolution - R510 - the ethical principles contained in R466 will prevail". Here we have a possible problem in interpreting whether or not the situation of non-voluntary participation was contemplated by R510. Our lay interpretation is that by proposing a new definition for "research participant" R510 contemplated the situation. We understand, however, that we have no legal basis for such a statement, and we wonder if the resolution should require this type of expertise from researchers and members of Ethics Committees.

We have observed so far that discussions similar to those faced by Milgram in the 1960s, regarding ethics in experimental research, are still present today. We understand that our research is simple if compared to Milgram's work, but we consider that the discussion is valid. We also emphasize that the objective is not to question the wording of the Resolutions, but to seek to interpret them, as well as to raise a greater debate 
within the academy in relation to the possibilities and obstacles to the use of financial incentives in experiments.

\section{Methodology}

This session presents the description of the method of the experimental essay. We describe the sample, the computational investment simulation used, the variables and design of the experiments and the statistical tests.

It has been exposed so far that there are different interpretations for CNS resolutions, and that there are few surveys that make use of financial incentives in Brazil. We present this essay with the purpose of exemplifying the use of incentives in experimental research, fostering the debate on the validity of incentives. For this, we analyze the influence of the use of financial incentives in the occurrence, or not, of the disposition effect in a simulation of computational investments.

\subsection{Sample}

Our sample is composed of approximately 30 individuals in each of the three types of experimental sessions performed (without incentive; continuous incentive; tournament incentive), a number that can be considered adequate, since most research in experimental economics uses similar samples (Smith, 1976; Smith et al., 1988). The total sample of the research, adding up all the sessions held, was 106 undergraduate students in business administration, economics and accounting at the Federal University of Santa Catarina. All students are from the early stages of the courses, so we expect to obtain a homogeneous level of knowledge among the participants.

\subsection{Computational Simulation of Investments}

In the process of developing this experiment, the participants receive verbal and textual (printed) instructions regarding the simulation of computational investments. The instructions include a projector demonstration of all system functionality, as well as a question-andanswer session and tests of buying and selling operations. Such procedures are commonly performed in economic experiments (Friedman \&
Sunder, 1994; Friedman \& Cassar, 2004). The total time of application varies according to the player, reaching a maximum time of 60 minutes and minimum of 20 minutes, the average time is 30 minutes.

The design of the experiment adopted in this research is based on the model used by Weber and Camerer (1998), but with implementation through a computerized system (Weber and Camerer used questionnaires). The computational simulation (ExpEcon) allows the recording of an output .txt file, containing a report of all transactions of purchase and sale of assets over each period simulated by the participant. This report allows the calculation of the returns and risks incurred, as well as the effects object of this research. ExpEcon has only one main screen, as shown in Figure 1.

\section{Figure 1. Main screen (ExpEcon)}



Source: prepared by the authors based on the software (2018).

4.3 Description of the variables and design of the experiment

The investment simulation software generates a text file with data on participants' buying and selling operations, as well as the composition of the participant's portfolio per period. From the output file of each participant, all information is aggregated, and the variables of interest are estimated and tabulated in an Excel spreadsheet that serves as a basis for econometric analysis.

The Coefficient of Disposition (CD), which shows the disposition effect, is the dependent variable of the research. This coefficient is calculated according to the method developed by

Revista de Negócios, v. 4, n. 24, p. 7-21, October, 2019. 
Odean (1998), by which the proportions of realized gains (PGR) and realized losses (PLR) of the participants are calculated. The objective of the experiment is to analyze whether PGR and PLR are affected according to the manipulations performed, which are the financial incentive conditions. For this purpose, three experiments are developed with different incentive procedures.

In the first one, we have the condition of control, without financial incentive ("without"), in which the participants do not receive any kind of financial incentive but learn about their relative performance (position in relation to the other participants) at the end of the simulation. Participants have their results measured by cash plus the amount invested in assets (final balance). This performance is kept confidential, i.e. the results are disclosed individually in an envelope. The participant receives the information of its final balance and its position in the ranking in relation to the other participants of the survey.

In the second condition we developed the experiment with financial incentive ("with"), and all participants are remunerated according to their performance. We call this format continuous payment. At the beginning of the experiment, all participants receive 10,000 monetary units to be used in investment simulation, in which 1,000 monetary units of the simulation are equivalent to $\mathrm{R} \$ 1$ in cash awards. For example, if at the end of the simulation the Final Balance, which appears on the simulation screen, is 15,000 monetary units, the subject receives $\mathrm{R} \$ 15.00$. If, on the other hand, the balance is 5,000 monetary units, the subject receives $\mathrm{R} \$ 5.00$. For comparison purposes, the hourly value of the minimum wage in 2017 is $\mathrm{R} \$ 5.85$ (for a 40-hour workweek). This performance is kept confidential, i.e. the results and awards are disclosed individually in an envelope. It should be noted that in the condition without incentive the participants also start with the same amount of monetary units, but do not receive any financial incentive, regardless of performance.

Finally, the third proposed condition is called tournament ("tournament"), where only the top three performers in the investment simulation are rewarded. The remuneration of the first place is $\mathrm{R} \$ 50$, the second place $\mathrm{R} \$ 25$ and the third place $\mathrm{R} \$ 10$. Performance is kept confidential, and participants receive their own rewards and performance information privately.
Members of all groups participate in an investment simulation with 30 rounds of up to 3 minutes each. The price data of the assets that make up the simulation are based on real asset data (traded on B3) or randomly assigned.

In addition to the conditions proposed in the three experiments, control variables were also used to analyze whether other factors can explain changes in the dependent variable.

a. Volatility: Average of the standard deviations of the assets that make up the participant's portfolio in each simulation period. This average is weighted by the percentage share of each asset in the participant's portfolio, and the standard deviation of each asset is calculated based on the historical price oscillation, that is, as the periods pass, the data set used to calculate the standard deviation of the asset increases. It is a reference for a possible strategy of "risk avoidance", observed by the oscillation of the assets, by the participant.

b. Cushion: Average of the percentage of resources that the participant keeps in cash in each period. Such a name is derived from a possible "cushion" strategy that the participants could adopt to avoid the embarrassment of remaining among the last placed. Example: A participant who has 10,000 monetary units and uses 1,000 monetary units to buy assets, keeping them in portfolio, has a Cushion of $90 \%$.

c. Turnover: Average percentage of funds (invested in assets plus cash) traded in relation to total funds (invested in assets plus cash) per period. Ex: A participant that has 10,000 monetary units (assets plus cash) and performs transactions equivalent to 5,000 monetary units has a turnover of $50 \%$. It is an alternative measure to the number of transactions, because it presents a reference number on the traded value, being more robust in this sense. It is a reference for a possible strategy of greater or lesser negotiation of the participant.

d. Assets in the portfolio: Average assets in the portfolio, ranging from 0 and 6 (total number of assets in the simulation). It presents a reference for a possible diversification strategy of the subject.

e. Transactions: Total number of buy and sell transactions performed per participant.

\subsection{Statistical tests}


The disposition effect calculation procedures are based on the method used by Odean (1998). The analysis can be performed individually (per subject) or with aggregated data from all participants (Odean, 1998; Shefrin \& Statman, 1985; Camerer, 1998). At the individual level, a proportion of realized gains and losses is calculated for each participant, and then averaged among the participants.

The analysis with aggregated data uses the sum of all gains and losses realized by all participants in one of the conditions. It is important to highlight that in the analysis at the individual level four averages of proportions are generated and the unit of analysis is "per participant" (a smaller sample). In the aggregate analysis four proportions are generated, and the unit of analysis is the set of operations of the participants (a larger sample).

Thus, for the analysis at the individual level, the $t$-test is performed to validate differences between means within the same group $(\mathrm{CD}=0)$, according to equations 1 and 2:

$$
t=\frac{P G R-P L R}{S E}
$$

Where the standard error is given by:

$$
S E=\frac{S}{\sqrt{n}}
$$

Where $\mathrm{S}$ is the standard deviation of the sample and $\mathrm{n}$ is the sample size.

In the aggregate level analysis, a t-test is performed to validate differences between proportions (ODEAN, 1998).

$$
t=\frac{P G R-P L R}{S E(P G R-P L R)}
$$

Where the standard error is given by:

$$
S E=\sqrt{\frac{P G R(1-P G R)}{N_{G R}+N_{G N R}}+\frac{P L R(1-P L R)}{N_{L R}+N_{L N R}}}
$$

To analyze the influence of the control variables on the disposition effect, multiple regressions are made (Wooldridge, 2010) in which the dependent variable is the Disposition Coefficient (DC). Equation 5 describes the proposed multiple regression model, performed in stepwise form, including the variables described in the previous section.

$$
\begin{aligned}
& D C_{i}=\alpha+\beta_{1 i} X_{1 i}+\beta_{2} X_{2 i}+\beta_{3} X_{3 i}+ \\
& \beta_{4} X_{4 i}+\beta_{5} X_{5 i}+\beta_{6} X_{6 i}+u_{i}
\end{aligned}
$$

Where $X_{1 i}=1$ is the binary variable for participants without incentive $\left(X_{1 i}=0\right.$ for the other conditions); $X_{2 i}$ is the mean of the standard deviation of the assets that make up the participant's portfolio in each simulation period (volatility); $X_{3 i}$ is the mean of the percentage of resources that the participant keeps in cash in each period (cushion); $X_{4 i}$ is the average of the percentage of resources (cash plus assets) traded in relation to the total resources (cash plus assets) per period (turnover); $X_{5 i}$ is the average of assets in portfolio, varies between 0 , and 6 which is the total number of assets of the simulation (average assets); $X_{6 i}$ is the total number of purchase and sale transactions made per participant (transactions).

\section{Analysis}

This session presents the results of the experiment, with analyses for the dependent variable: DC and its PLR and PGR composition bases. It should be noted that the purpose of the experiment is to test whether the financial incentive has an impact on the DC, compared to a condition in which the participants do not receive financial incentive. The general literature on the subject "financial incentive" is not conclusive (Camerer \& Hogarth, 1999), depending on the task the incentive can improve the result or harm it. So far there is no knowledge of this type of analysis, specifically related to the disposition effect. Thus, we start the experiment without any expectation of its influence or direction.

In the condition of continuous incentive, where all subjects received the financial value according to their performance, we recorded as worst performance $-17.71 \%$. In this case the subject had a loss of approximately $\$ 1.70$ of the $\$ 10.00$ that initially received, ending the simulation with the value of $\$ 8.30$. The best performance was $22.25 \%$ which generated a final received amount of $\$ 12.25$. Table 1 presents the descriptive statistics at the individual level. 
Table 1. Descriptive statistics for individual DCs.

\begin{tabular}{|c|c|c|c|c|}
\hline & Total & Sem & Com & Torneio \\
\hline Average PGRi & 0,1747 & 0,2126 & 0,1658 & 0,1407 \\
\hline Average PLRi & 0,1558 & 0,1134 & 0,1762 & 0,1866 \\
\hline Average DCi & 0,0189 & 0,0992 & $-0,0104$ & $-0,0459$ \\
\hline Median DCi & 0,0105 & 0,0384 & 0,0088 & $-0,0410$ \\
\hline Max DCi & 0,7756 & 0,7756 & 0,2429 & 0,3646 \\
\hline Min DCi & $-0,6154$ & $-0,2714$ & $-0,4643$ & $-0,6154$ \\
\hline $\begin{array}{l}\text { Standard Error DCi } \\
\text { t-test for the mean }\end{array}$ & 0,2018 & 0,1967 & 0,1648 & 0,2056 \\
\hline $\mathrm{DCi}=0$ & 0,9421 & $3,1504 * * *$ & $-0,3157$ & $-1,3587$ \\
\hline$(p$-value - two-tail $)$ & $(0,1730)$ & $(0,0008)$ & $(0,6238)$ & $(0,9128)$ \\
\hline$n$ & 101 & 39 & 25 & 37 \\
\hline
\end{tabular}

The analysis shows that in the condition without incentive the DC was positive. In the conditions with continuous incentive and tournament the DC was not significant, that is, the subjects presented a rational behavior, confirming the evidences of Holm et al. (2013) that financial incentives improve participant performance.

Table 2 presents the descriptive statistics at the aggregate level. Once again it is possible to observe the occurrence of the disposition effect on the condition without. However, considering the aggregated data, it is also possible to observe a positive DC for the condition with. The most significant difference between the conditions occurred in the PGR, and at the aggregate level it was also possible to observe significantly higher DC in the condition without in comparison with the two incentive conditions.

Table 2. Descriptive Statistics for Aggregated DCs

\begin{tabular}{lcccc}
\hline & Total & Sem & Com & Torneio \\
\hline $\begin{array}{l}\text { Realized Gains } \\
\text { (RG) }\end{array}$ & 740 & 379 & 166 & 195 \\
$\begin{array}{l}\text { Realized Losses } \\
\text { (RL) }\end{array}$ & 545 & 224 & 131 & 190 \\
$\begin{array}{l}\text { Unrealized Gains } \\
\text { (UG) }\end{array}$ & 4306 & 1797 & 1016 & 1493
\end{tabular}

\begin{tabular}{lcccc}
$\begin{array}{l}\text { Unrealized losses } \\
\text { (UL) }\end{array}$ & 3496 & 1526 & 954 & 1016 \\
PGR=RG/(RG+UG) & 0.1467 & 0.1742 & 0.1404 & 0.1155 \\
PLR=RL/(RL+UL) & 0.1349 & 0.1280 & 0.1207 & 0.1575 \\
DC=PGR-PLR & 0.0118 & 0.0462 & 0.0197 & -0.0420 \\
Standard Error & 0.0073 & 0.0114 & 0.0141 & 0.0131 \\
Z stat & $1.6083 *$ & $4.0514 * * * 1.3932^{*}$ & -3.2176 \\
(p-value) & $(-.0538)$ & $(.0000)$ & $(.0817)$ & $(.9993)$ \\
Final sample & 101 & 39 & 25 & 37 \\
\hline Aggrgated & & & &
\end{tabular}

Aggregated level

(1) One tail test: Null hypothesis: $\mathrm{DC} \leq 0$; Alternative hypothesis: DC $>0$

(2) Comparing PGRs between conditions without and with incentive: Without: $379 / 2176(=0.1742) \quad$ vs. With 166/1182(=0.1404), $\quad Z=3.7922 * * *$ Comparing $\quad$ PGR between conditions without and tournament: Without: $379 / 2176(=0.1742)$ vs. Tournament: 195/1688(=0.1155), Z=6.8423*** Comparing PGR between conditions without and tournament: without: $379 / 2176(=0.1742) \quad$ vs. $\quad$ Tournament $195 / 1688(=0.1155)$, $\mathrm{Z}=6.8423^{* * * *}$

(3) Comparing PLR between conditions without and with incentives: Without: 224/1750 $(=0.1280)$ vs. With: 131/1085(=0.1207), $\mathrm{Z}=1.3933^{*}$ Comparing PGR between conditions without and tournament: Without: $224 / 1750(=0.1280)$ vs. Tournament: 195/1688(=0.1155), $\mathrm{Z}=6.8423 * * *$ Comparing PLR between conditions without and tournament: Without: $379 / 2176(=0.1742)$ vs. Tournament $190 / 1206(=0.1575), Z=-$ 3,2176

(4) Test to verify if DC (without) $\geq \mathrm{DC}$ (with) using SE from the total sample: $\mathrm{Z}=(0.0462-0.0197) / 0.0089=$ $2.9758 * * *$ Test to verify if DC (without) $\geq \mathrm{DC}$ (tournament) using SE from the total sample: $Z=[0.0462-(-$ $0.0420)] / 0.0086=10.2891 * * *$

(5) $*$ significant at $10 \%$; ** significant at 5\%; *** significant at $1 \%$.

The results we found are significant and show that, at first sight, there is an influence of the incentive condition on the DC. However, this influence could be caused by a series of factors not related to the incentive. For this reason, tests are performed to verify whether these other factors could explain the variation observed in DC. Multiple regressions are performed in stepwise form, including the control variables already described. 
Table 3. Regressions for control variables with and without incentive.

\begin{tabular}{|c|c|c|c|c|c|c|}
\hline DC & Model 1 & Model 2 & Model 3 & Model 4 & Model 5 & Model 6 \\
\hline \multirow{2}{*}{ Interc. } & -0.0104 & 0.0627 & 0.2099 & 0.2352 & 0.2659 & 0.4429 \\
\hline & $(0.0370)$ & $(0.0712)$ & $(0.1288)$ & $(0.1283)$ & $(0.1473)$ & $(0.1811)$ \\
\hline \multirow{2}{*}{$1=$ without $0=$ with } & $0.1096^{*}$ & 0.0829 & 0.0454 & 0.0719 & 0.0734 & 0.0172 \\
\hline & $(0.0474)$ & $(0.0522)$ & $(0.0587)$ & $(0.0604)$ & (0.0609) & $(0.0692)$ \\
\hline \multirow{2}{*}{ Volat. } & & -0.0192 & $-0.0369^{*}$ & -0.0288 & -0.0307 & -0.0385 \\
\hline & & $(0.0160)$ & $(0.0205)$ & $(0.0210)$ & $(0.0215)$ & $(0.0217)$ \\
\hline \multirow{2}{*}{ Cushion } & & & -0.1502 & -0.1583 & -0.1637 & $-0.2362 * *$ \\
\hline & & & $(0.1099)$ & $(0.1088)$ & (0.1102) & $(0.1173)$ \\
\hline \multirow{2}{*}{ Trans. } & & & & -0.0016 & -0.0015 & -0.0010 \\
\hline & & & & $(0.0010)$ & $(0.0011)$ & $(0.0011)$ \\
\hline \multirow{2}{*}{ Average share } & & & & & -0.0087 & -0.0281 \\
\hline & & & & & (0.0199) & $(0.0230)$ \\
\hline \multirow{2}{*}{ Turnover } & & & & & & -0.9004 \\
\hline & & & & & & $(0.5499)$ \\
\hline $\mathrm{R}^{2}$ & 0.0646 & 0.0712 & 0.0842 & 0.1057 & 0.0932 & 0.1188 \\
\hline $\mathrm{n}$ & 64 & 64 & 64 & 64 & 64 & 64 \\
\hline
\end{tabular}

(1) The table presents the coefficient, and in parentheses the robust standard error. In bold, the adjusted $\mathrm{R}^{2}$.

(2) $D C_{i}=\alpha+\beta_{1} X_{1 i}+\beta_{2} X_{2 i}+\beta_{3} X_{3 i}+\beta_{4} X_{4 i}+\beta_{5} X_{5 i}+\beta_{6} X_{6 i}+u_{i}$

Where $X_{1 i}=1$ is the binary variable for participants in "without" setting and $X_{1 i}=0$ for the "whit" setting; $X_{2 i}$ is the average standard deviation of the assets comprising the portfolio of each participant in the simulation period. This average is weighted by the percentage share of each asset in the portfolio of the participant, and the standard deviation of each asset is calculated based on price fluctuations, i.e., as rounds are played, the data set used to calculate the standard deviation of the asset increases (Volatility); $X_{3 i}$ is the average percentage of his total assets that the participant keeps in cash each period as a proportion of total equity (Cushion); $X_{4 i}$ is the total number of buy and sell per participant (Trans.); $X_{5 i}$ is the average number of stocks held in portfolio, varying between 0 and 6 , which is the total number of options in the simulation(average share); $X_{6 i}$ is the average percentage of investment assets traded in relation to total assets (investments plus cash) per period (Turnover). For example: a participant who has a total of 10,000 monetary units (investments plus cash balance) who trades 5000 monetary units has a turnover of $50 \%$.

(3) The total sample includes 69 participants. Five participants are excluded due to data capture error in the simulation software. A similar procedure was adopted in Dhar and Zhu (2006).

(4) White's (1980) regression correction was employed: heteroskedasticity-consistent standard errors.

(5) *Significant at $10 \%$; **significant at $5 \%$; ***significant at $1 \%$.

Analyzing the conditions without and with continuous incentive (Table 3) it was not possible to observe explanatory power for the proposed models. Significance was found in model 1 for incentive conditions, and in model 6 for the cushion variable, which is the cash value that the subject maintains, as a kind of "earnings cushion".

Analyzing the conditions without and tournament (Table 4) we found more significant results. For all models the incentive manipulation was significant. The volatility variable was also relevant to explain the variations in the DC.

A possible explanation for this difference is the fact that the subjects of the tournament condition had as a basis of the oscillation of the simulation assets a random generation of movements of high and low, similar to that adopted in Weber and Camerer (1998). While in the other conditions, market data were essentially used. This change in the type of variation (random or real data) was not part of the initial proposal of this research and is undoubtedly a point to be taken into consideration in future research.

Even so, analyzing the data in Table 4, we can conclude that the manipulation of remuneration is one of the main explanatory variables for the changes in the DC.

One of the points addressed here was the issue of salience, which is a basic premise of experimental economics (Smith, 1982). According to this premise, participants have the right to claim a reward that will be increasing or decreasing according to the results. We observed that the absence of a financial reward/incentive tends to

Revista de Negócios, v. 4, n. 24, p. 7-21, October, 2019. 
Table 4. Regressions for control variables with and without incentive.

\begin{tabular}{|c|c|c|c|c|c|c|}
\hline CD & Model 1 & Model 2 & Model 3 & Model 4 & Model 5 & Model 6 \\
\hline \multirow{2}{*}{ Interc. } & -0.0459 & 0.0425 & 0.1345 & 0.1545 & 0.2990 & 0.1993 \\
\hline & $(0.0331)$ & 0.0694 & 0.0984 & 0.1009 & 0.1205 & 0.1331 \\
\hline \multirow{2}{*}{$\begin{array}{c}1=\text { =without } \\
0=\text { tournament }\end{array}$} & $0.1451 * * *$ & $0.1015^{* *}$ & $0.0975^{* *}$ & $0.1139 * *$ & $0.1183 * *$ & $0.1635^{* * *}$ \\
\hline & $(0.0461)$ & 0.0548 & 0.0546 & 0.0575 & 0.0562 & 0.0618 \\
\hline \multirow{2}{*}{ Volat. } & & -0.0186 & $-0.0280 * *$ & $-0.0256^{* *}$ & $-0.0332 * *$ & $-0.0326^{* *}$ \\
\hline & & 0.0129 & 0.0147 & 0.0150 & 0.0151 & 0.0149 \\
\hline \multirow{2}{*}{ Cushion } & & & -0.1464 & -0.1512 & -0.1474 & -0.1134 \\
\hline & & & 0.1116 & 0.1119 & 0.1093 & 0.1099 \\
\hline \multirow{2}{*}{ Trans. } & & & & -0.0010 & -0.0001 & -0.0010 \\
\hline & & & & 0.0010 & 0.0011 & 0.0012 \\
\hline \multirow{2}{*}{ Average share } & & & & & $-0.0444 * *$ & -0.0275 \\
\hline & & & & & 0.0213 & 0.0233 \\
\hline \multirow{2}{*}{ Turnover } & & & & & & $0.5453^{*}$ \\
\hline & & & & & & 0.3268 \\
\hline $\mathrm{R}^{2}$ & 0.1060 & 0.1190 & 0.1276 & 0.1258 & 0.1652 & 0.1860 \\
\hline $\mathrm{n}$ & 76 & 76 & 76 & 76 & 76 & 76 \\
\hline
\end{tabular}

(1) The table presents the coefficient, and in parentheses the robust standard error. In bold, the adjusted $\mathrm{R}^{2}$.

(2) $D C_{i}=\alpha+\beta_{1} X_{1 i}+\beta_{2} X_{2 i}+\beta_{3} X_{3 i}+\beta_{4} X_{4 i}+\beta_{5} X_{5 i}+\beta_{6} X_{6 i}+u_{i}$

Where $X_{1 i}=1$ is the binary variable for participants in "without" setting and $X_{1 i}=0$ for the "tournament" setting; $X_{2 i}$ is the average standard deviation of the assets comprising the portfolio of each participant in the simulation period. This average is weighted by the percentage share of each asset in the portfolio of the participant, and the standard deviation of each asset is calculated based on price fluctuations, i.e., as rounds are played, the data set used to calculate the standard deviation of the asset increases (Volatility); $X_{3 i}$ is the average percentage of his total assets that the participant keeps in cash each period as a proportion of total equity (Cushion); $X_{4 i}$ is the total number of buy and sell per participant (Trans.); $X_{5 i}$ is the average number of stocks held in portfolio, varying between 0 and 6 , which is the total number of options in the simulation(average share); $X_{6 i}$ is the average percentage of investment assets traded in relation to total assets (investments plus cash) per period (Turnover). For example: a participant who has a total of 10,000 monetary units (investments plus cash balance) who trades 5000 monetary units has a turnover of $50 \%$.

(3) The total sample includes 69 participants. Five participants are excluded due to data capture error in the simulation software. A similar procedure was adopted in Dhar and Zhu (2006).

(4) White's (1980) regression correction was employed: heteroskedasticity-consistent standard errors.

(5) * Significant at $10 \%$;**ignificant at $5 \%$; ***significant at $1 \%$.

increase the DC, and that the use of a continuous incentive, as recommended, reduces the DC. We also observed that when the incentive is directed only to the best performances, the changes in the DC are even more significant when compared to the situation without incentives.

A broader discussion on the influence of incentives on the DC, or performance of the participants, could be held, but this is not the intention of this work. We conclude this session with sufficient evidence, with respect to the essay presented, to demonstrate the importance of debating the issue of whether or not to allow the use of financial incentives in the scientific community. We observed that there is a real impact on the results.

\section{Conclusion}

The main objective of this study was to evaluate the impact of the use of financial incentives in experiments in the area of economics and finance. We have shown that the interpretation of National Health Council (CNS) Resolutions 466 and 510 may present obstacles to the adoption of such a method. We argue that the wording of R466 demonstrates a legitimate concern with the ethical issue in health research, however for experimental research in the area of economics and finance its wording is not clear, which is also not clarified in R510.

By offering clear regulation, the CNS offers support and limits for the Ethics Committees to present their manifestations. We do not believe 
that it is the regulator's intention to offer an obstacle to conducting research in the field of experimental economics; we believe that there is a simple lack of greater debate with the scientific community.

Understanding that other areas of science require much greater attention and demand from the Ethics Committees, we consider that it is up to the interested parties (researchers) to demonstrate that their respective research deserves attention. On the other hand, we hope that the regulator can offer all his expertise and propose a regulation that takes into account the particularities of experimental economic science.

We present adequate literature to stimulate the debate, even though and corroborating with other researches, we demonstrate through an essay how the offer or not of financial incentive can alter the results of an economic experiment conducted in laboratory. From the results presented, we demonstrated that the use of financial incentives can influence the disposition effect, a bias of judgment widely debated in the field of behavioral economics.

With these results we were able to contribute to minimize the gap in the Brazilian context about financial incentives. As presented, only one study used a national sample to assess the impact of financial incentives on results of experimental studies (Soares, Simões \& Jorge Neto, 2018) and there is a need to expand these results, because even if internationally we have studies that prove this influence, we live in a different context which can change the results.

In practice, this discussion contributes to alerting future studies to pay attention to financial incentives issues in their research, because they can effectively change their performance. At a theoretical level, our interest in this article was to foster the discussion, which in no way closes with the evidence presented here, nor even brings solutions. But on the other hand, it recovers and encourages critical thinking about financial incentives in experiments in the area of economics and finance, even because science is a continuous process, not consolidating itself as an absolute truth.

In light of this, the need for further studies on the subject is emphasized, considering other types of incentives, as well as samples with different characteristics. It is also suggested that future studies incorporate other variables, so that we can broaden the understanding on the impact of financial incentives and other behavioral biases. As a limitation of the study, the composition of the sample stands out, as we had three experimental groups, we needed a significant number of people and we had difficulty attracting a greater number of students to the experiment. In this context, we assumed that there may be sample selection bias, because possibly those students who showed interest in the subject participated in the study.

\section{References}

Ariely, D., \& Norton, M. I. (2007). Psychology and experimental economics: A gap in abstraction. Current Directions in Psychological Science, 16(6), 336-339.

Antiqueira, J. R. M., Saes, M. S. M., \& Lazzarini, S. G. (2007). Comportamento oportunista em negociações envolvendo investimentos específicos: um estudo com metodologia experimental. Revista de AdministraçãoRAUSP, 42(4), 393-404.

Aspara, J., \& Hoffmann, A. O. (2015). Selling losers and keeping winners: How (savings) goal dynamics predict a reversal of the disposition effect. Marketing Letters, 26(2), 201-211. doi: 10.1007/s11002-013-9275-9

Barberis, N., \& Xiong, W. (2012). Realization utility. Journal of Financial Economics, 104(2), 251-271. doi: org/10.1016/j.jfineco.2011.10.005

Brasil (2012). Ministério da Saúde. Conselho Nacional de Saúde. Resolução $n^{\circ}$ 466, de 12 de dezembro de 2012. Diário Oficial [da] República Federativa do Brasil, Brasília. Recuperado de http://bvsms.saude.gov.br/bvs/saudelegis/cns/201 3/res0466_12_12_2012.html.

Brasil (2016). Ministério da Saúde. Conselho Nacional de Saúde. Resolução $\mathrm{n}^{\circ} 510$, de 7 de abril de 2016. Diário Oficial [da] República Federativa do Brasil, Brasília. Seção 1. p. 44-46. Disponível em: http://conselho.saude.gov.br/resolucoes/2016/Res o510.pdf.

Bricker, J. (2014). Survey Incentives, Survey Effort, and Survey Costs. Finance and Economics Discussion Series (FEDS). Working Paper No. 2014-74. Recuperado de

Revista de Negócios, v. 4, n. 24, p. 7-21, October, 2019. 
https://ssrn.com/abstract=2503478.

Calvet, L.; Campbell, J. \& Sodini, P. (2009). Fight or flight? Portfolio rebalancing by individual investors. Quarterly Journal of Economics, 124(1), 301-348.

Camerer, C. \& Hogarth, R. (1999). The effects of financial incentives in experiments: A review and capital- labor production theory. Journal of Risk and Uncertainty, 19(1). doi: 10.1007/978-94-0171406-8_2

Cárdenas, J. C., De Roux, N., Jaramillo, C. R., \& Martinez, L. R. (2014). Is it my money or not? An experiment on risk aversion and the house-money effect. Experimental Economics, 17(1), 47-60. doi: 10.1007/s10683-013-9356-x

Carpena, F.; Cole, S.; Shapiro, J. \& Zia, B. (2015). The ABCs of Financial Education. Policy Research. Working Paper No. 7413. Recuperado de

https://papers.ssrn.com/sol3/papers.cfm?abstract_i $\mathrm{d}=2661139$.

Chen, G., Kim, K. A., Nofsinger, J. R., \& Rui, O. M. (2007). Trading performance, disposition effect, overconfidence, representativeness bias, and experience of emerging market investors. Journal of Behavioral Decision Making, 20(4), 425-451. doi: 10.1002/bdm.561

Costa, C. B. D. S., Prado, P. H. M., Mantovani, D., Korelo, J. C., Niada, A. C. M., \& Semprebon, E. (2014). Investimento percebido, custo de resgate e tipo de recompensa na intenção de adesão a programas de fidelidade. Revista Base (Administração e Contabilidade) da UNISINOS, 11(3), 193-203. doi: 10.4013/base.2014.113.02

Da Costa, N., Goulart, M., Cupertino, C., Macedo, J., \& Da Silva, S. (2013). The disposition effect and investor experience. Journal of Banking \& Finance, 37(5), 1669-1675. doi: org/10.1016/j.jbankfin.2012.12.007

Dantas, J. A., Dantas, J. M. M., \& Silva, C. A. T. (2012). O efeito de estímulos morais e éticos como resposta ao problema do risco moral: uma verificação experimental em grupos de estudantes. Contextus-Revista Contemporânea de Economia e Gestão, 10(2). doi:

De Lima, P. A., Porto, R. B., \& Botelho, D. (2016). Interatividade em anúncios: efetividade da produção publicitária nas avaliações dos consumidores. Revista Base (Administração e Contabilidade) da UNISINOS, 13(2), 138-152. doi: 10.4013/base.2016.132.04

Derman, E. (2004). My life as a quant: reflections on Physics and Finance. John Wiley \& Sons.

Dhar, R., \& Zhu, N. (2006). Up close and personal: Investor sophistication and the disposition effect. Management Science, 52(5), 726-740. doi: org/10.1287/mnsc.1040.0473

dos Santos, L. P. G. (2015). Comparando o uso de mensuração forward-looking e contemporânea de desempenho na formulação de contratos de incentivo quando existe o problema do horizonte: uma análise experimental. Revista Contabilidade \& Finanças-USP, 26(68), 195-207. doi: $10.1590 / 1808-057 \times 201501060$

Endlich, L., (2000). Goldman Sachs: The Culture of Success. Touchstone.

Feltovich, N. (2011). What's to Know About Laboratory Experimentation in Economics? Journal of Economic Surveys, 25(2), 371-379. doi: 10.1111/j.1467-6419.2010.00676.x

Feng, L., \& Seasholes, M. S. (2005). Do investor sophistication and trading experience eliminate behavioral biases in financial markets? Review of Finance, 9(3), 305-351. doi: org/10.1007/s10679005-2262-0

Friedman, D. \& Cassar, A. (2004). Economics Lab: An Intensive Course in Experimental Economics. Routledge.

Friedman, D. \& Sunder, S. (1994). Experimental Methods: A Primer for Economists. New York: Cambridge University Press.

Goulart, M., Da Costa Jr, N., Santos, A., Takase, E., \& Da Silva, S. (2013). Psychophysiological correlates of the disposition effect. PloS One, 8(1), e54542. doi: org/10.1371/journal.pone.0054542

Goulart, M.; Da Costa Jr., N.; Andrade, E. B. \& Santos, A. A. P. (2015). Hedging against embarrassment. Journal of Economic Behavior \& Organization, 116(4), 310-318. doi: org/10.1016/j.jebo.2015.04.014

Harrison, G. W. (1989). Theory and misbehavior of first-price auctions. American Economic Review, 79(4),749-762. 
Holm, H. J., Opper, S., \& Nee, V. (2013). Entrepreneurs under uncertainty: An economic experiment in China. Management Science, 59(7), 1671-1687. doi: org/10.1287/mnsc.1120.1670

Hertwig, R., \& Ortmann, A. (2001). Experimental practices in economics: A methodological challenge for psychologists? Behavioral and Brain Sciences, 24(03), 383-403. doi: org/10.1017/S0016774600023726

Iwai, T., \& Azevedo, P. F. D. (2016). Economic incentives or communication: how different are their effects on trust. BAR-Brazilian Administration Review, 13(3). Doi: org/10.1590/1807-7692bar2016160032

Kahneman, D. \& Tversky, A. (1979). Prospect theory: An analysis of decision under risk. Econometrica, 47, 263-292. doi: jstor.org/stable/1914185

Kaustia, M. (2010). Prospect Theory and the Disposition Effect. Journal of Financial and Quantitative Analysis, 45( 3), 791-812. doi: org/10.1017/S0022109010000244

Milgram, S. (1963). Behavioral study of obedience. Journal of Abnormal and Social Psychology, 67(4),371 doi: org/10.1037/h0040525

Odean, T. (1998). Are investors reluctant to realize their losses? Journal of Finance, 53(5), 1775-1798. doi: 10.1111/0022-1082.00072

Passos, I, C; Cornacchione Jr, E B; Gaio, L E \& Brito, E. Raciocínio crítico em ambientes virtuais. Revista de Contabilidade e Organizações, 26(1), 77-88. doi: org/10.11606/rco.v10i26.111420

Póvoa, A. C. S., Maffezzolli, M. R., Pech, W., \& Silva, W. V. D. (2017). A influência do Gênero no processo decisório: o jogo do ultimato. Revista de Administração Contemporânea, 21(4), 481-499.

Shefrin, H., \& Statman, M. (1985). The disposition to sell winners too early and ride losers too long: Theory and evidence. The Journal of finance, 40(3), 777-790. doi: 10.1111/j.15406261.1985.tb05002.x

Smith, V. L. (1962). An experimental study of competitive market behavior. Journal of political economy, 70(2), 111-137.

Smith, V. L. (1976). Experimental economics: Induced value theory. The American Economic Review, 66(2), jstor.org/stable/1817233

Smith, V. L. (1982). Microeconomic systems as an experimental science.The American Economic Review. 72(5), 923-955.

Smith, V. L.; Suchanek, G. L. \& Williams, A. (1988). Bubbles, Crashes, and Endogenous Expectations in Experimental Spot Asset Markets. Econometrica, 56(5), 1119-1151. doi: jstor.org/stable/1911361

Soares, R. B., Simões, P., \& Jorge Neto, P. D. M. (2018). Aversão ao risco e efeito incentivo: um experimento laboratorial com alunos da UFC. Contextus: Revista Contemporânea de economia e gestão, 16(1), 10-33.

Summers, B., \& Duxbury, D. (2012). Decisiondependent emotions and behavioral anomalies. Organizational Behavior and Human Decision Processes, 118(2), 226-238. doi: org/10.1016/j.obhdp.2012.03.004

Times (2014). Ranking Times Higher Education 2013-2014. Recuperado de https://www.timeshighereducation.com

Weber, M., \& Camerer, C. F. (1998). The disposition effect in securities trading: An experimental analysis. Journal of Economic Behavior \& Organization, 33(2), 167-184. doi: org/10.1016/S0167-2681(97)00089-9

Wooldridge, J. M. (2010) Econometric analysis of cross-section and panel data. 2a. Ed., Cambridge, MA: MIT Press. 